\title{
Diversity and Plant Growth-Promotion of Endophytic Fungi Isolated from the Roots of Plants in Dokdo Islands
}

Young-Hyun You, Hyeokjun Yoon, Gil Seong Lee', Ju-Ri Woo, Jae-Ho Shin², In-Jung Lee', Soon-Ok Rim, Yeon-Sik Choo ${ }^{1}$ and Jong-Guk Kim*

\author{
Department of Life Sciences and Biotechnology, Kyungpook National University, Daegu 702-701, Korea \\ ${ }^{1}$ Department of Biology, College of National Sciences, Kyungpook National University, Daegu 702-701, Korea \\ ${ }^{2}$ School of Applied Biosciences, Kyungpook National University, Daegu 702-701, Korea
}

Received April 5, 2011 /Revised May 17, 2011 /Accepted May 18, 2011

\begin{abstract}
Endophytic fungi were isolated from the roots of plants growing naturally on the island of Dokdo. Plant samples, such as Miscanthus sinensis, Achyranthus japonica and Echinochloa crusgali were isolated from Dongdo, and those such as Honkenya peploides and Artemsia koidzumii were isolated from Seodo. Twenty one strains of endophytic fungi were isolated from these plants. To identify the strains, PCR (polymerase chain reaction) amplification of the partial ITS (Internal Transcribed Spacer) regions was done with universal primers ITS- 1 and ITS- 4 to determine the nucleotide sequence of the ITS regions. Of the strains isolated from Miscanthus sinensis, $75 \%$ were Penicillium sp. and $25 \%$ were Aspergillus sp. Fifty five percent of strains isolated from Achyranthus japonica were Penicillium sp., $30 \%$ were Aspergillus sp. and 15\% were Zygorhynchus sp. Strains isolated from Echinochloa crusgali were Penicillium sp. (50\%), Aspergillus sp. (12\%), Giberella sp. (13\%), Talaromyces sp. (9\%) and Umbelopsis sp. (8\%). Of the strains isolated from Honkenya peploides, $76 \%$ were Penicillium sp. and $24 \%$ were Pestalotiopsis sp. Strains isolated from Artemisia koidzumii were Penicillium sp. (81\%) and Mucor sp. $(19 \%)$. As a result of bioassay, Ec-3-1 strain isolated from Echinochloa crusgalli showed plant growth-promotion activity. Of all the endophytic fungi isolated, Penicillium sp. was the most abundantly distributed fungal strain in all plants used in this study.
\end{abstract}

Key words : Dokdo islands, endophytic fungi, diversity, rDNA-ITS, plant growth-promotion

\section{서 론}

독도는 북서태평양 연해인 동해의 남부와 울릉분지 북쪽 경계에 위치(E $\left.131^{\circ} 52^{\prime} 07^{\prime \prime}, \mathrm{N} 37^{\circ} 14^{\prime} 12^{\prime \prime}\right)$ 하고 있는 해양 성 화산도이다. 한류와 난류가 만나 완대류를 형성하고 있으 며 연평균 $12^{\circ} \mathrm{C}$ 의 기온을 나타내고 눈과 비가 오는 날이 많으 며, 급경사 지역이 대부분을 차지하고 있고 강한 바람의 영향 으로 식물이 서식하기에는 악조건이다. 독도는 크게 동도와 서도로 구분되고, 89 개의 작은 부속 섬들로 이루어져 있으며, $40^{\circ}$ 이상이나 되는 급사면은 $65.4 \%$ 를 이루고 있어 급경사가 많은 지역이다[2,3]. 그리고 독도의 토양은 화산활동에 의해 형성되었으며, 매우 건조하고 염분함량이 높으며 유기영양분 과 광조건이 상당히 부족하다[14,16]. 그리고 독도는 내륙과 격리되어 있으며, 온난 다습한 기후로 인하여 한반도와는 다 른 특수한 식물상 및 식물군락을 형성하고 있다. 독도는 고유 한 생태적 및 경관적 가치에 따라「문화재보호법」에 의한 천 연기념물로 지정되어 관리되고 있다. 독도의 식물상에 대한 연구는 1952년부터 수행되었으며[2,4,12-17], 48종의 식물이 자 생하고 있는 것으로 알려졌다[2,4,10-13,15].

*Corresponding author Tel : +82-53-950-5379, Fax : +82-53-955-5379 E-mail : kimjg@knu.ac.kr
독도의 미생물에 관한 연구는 식물근권세균(PGPR) 및 새 로운 미생물종이 발견될 가능성이 상당히 높은 지역으로 알려 져 있다[2,4,17].

내생진균 중에는 식물의 생장에 관여하는 식물생장호르몬인 $\mathrm{GA}$ (gibberellin), $\mathrm{ABA}$ (abscisic acid) 등을 생산하는 균주가 포 함된 것으로 알려져 있으며, 이를 이용한 생물적 방제에 대한 연구도 증가 하고 있다[1,5-9]. 그러나 독도에서는 식물뿌리 내생 진균을 포함한 진균에 관한 연구는 아직까지 알려져 있지 않다.

본 연구에서는 동도에 서식하고 있는 참억새(Miscanthus sinensis)와 쇠무릎(Achyranthes japonica) 그리고 돌피 (Echinochloa crusgalli), 서도에 서식하고 있는 갯별꽃(Honkenya peploides)과 율무쑥(Artemisia koidzumil)의 뿌리에서 공생 및 상호작용 관계에 있는 내생진균을 확인하기 위하여 이들 식물 뿌리 내부에서 진균류를 분리하여, rDNA-ITS 영역을 이용하 여 동정하였으며, 내생진균이 가지는 식물생장촉진활성을 검 정하기 위하여 bioassay를 수행하였고, 이들 균주의 다양성에 대하여 조사하였다[5-9,14].

\section{재료 및 방법}

식물시료는 동도(dongdo)에서 참억새와 쇠무릎 및 돌피를 
Table 1. Location of the five plants in Dokdo islands

\begin{tabular}{llc}
\hline Plant names & Geographic coordinates & Local \\
\hline Miscanthus sinensis & $\mathrm{E} 131^{\circ} 51^{\prime} 52^{\prime \prime} / \mathrm{N} 37^{\circ} 14^{\prime} 30^{\prime \prime}$ & Dongdo \\
Achyranthes japonica & $\mathrm{E} 131^{\circ} 51^{\prime} 53^{\prime \prime} / \mathrm{N} 37^{\circ} 14^{\prime} 37^{\prime \prime}$ & Dongdo \\
Echinochloa crusgalli & $\mathrm{E} 131^{\circ} 51^{\prime} 53^{\prime \prime} / \mathrm{N} 37^{\circ} 14^{\prime} 38^{\prime \prime}$ & Dongdo \\
Honkenya peploides & $\mathrm{E} 131^{\circ} 51^{\prime} 34^{\prime \prime} / \mathrm{N} 37^{\circ} 14^{\prime} 40^{\prime \prime}$ & Seodo \\
Artemisia koidzumii & $\mathrm{E} 131^{\circ} 51^{\prime} 35^{\prime \prime} / \mathrm{N} 37^{\circ} 14^{\prime} 39^{\prime \prime}$ & Seodo \\
\hline
\end{tabular}

채취하였고, 서도(Seodo)에서 갯별꽃과 율무쑥을 채취 하였 다(Table 1). 본 연구는 독도에 서식하는 식물의 뿌리로부터 분리한 내생진균을 사용하였고, 한국미생물보존센터(KCCM) 로부터 분양받은 Gibberella fujikuroi (KCCM 12329) 균주를 control로 사용하였으며, 식물생장촉진활성 검정인 bioassay 시험을 위하여 식물시료는 난장이벼(waito-c)를 사용하였다.

독도의 동도와 서도에서 채취한 식물 시료의 뿌리부분을 절단하여 흙을 모두 제거하고, 계면활성제인 Tween 80 을 첨 가하고 10 분간 교반 한 후에 증류수로 세척하였다. 그리고 과 염소산(Perchloric acid) $1 \%$ 에 10분간 2회 교반 후, 증류수로 세척하였으며 $3 \sim 4 \mathrm{~cm}$ 로 절단하여 수분을 제거하였다. 그리고 내생진균를 분리하기 위하여 Hagem medium $(0.5 \%$ Glucose, $0.05 \% \mathrm{KH}_{2} \mathrm{PO}_{4}, 0.05 \% \mathrm{MgSO}_{4} \cdot 7 \mathrm{H}_{2} \mathrm{O}, 0.05 \% \mathrm{NH}_{4} \mathrm{Cl}, 0.05 \%$ $\mathrm{FeCl}_{3}, 0.1 \%$ Streptomycin, $\mathrm{pH}$ 5.6)를 사용하여 $25^{\circ} \mathrm{C}$ 에서 배양 하였다. 그리고 PDA medium $(0.4 \%$ Potato peptone, $2 \%$ Glucose, $1.5 \% \mathrm{Agar})$ 에 옮겨 $25^{\circ} \mathrm{C}$ 조건에서 계대배양하여 순 수 분리하였다[5-9].

독도식물 뿌리에서 분리한 내생진균를 배양하기 위하여 Czapek's liquid medium (1\% Glucose, 1\% Bacto-peptone, $0.1 \% \mathrm{KH}_{2} \mathrm{PO}_{4}, 0.05 \% \mathrm{KCl}, 0.05 \% \mathrm{MgSO}_{4} \cdot 7 \mathrm{H}_{2} \mathrm{O}, 0.001 \%$ $\mathrm{FeSO}_{4} \cdot 7 \mathrm{H}_{2} \mathrm{O}, \mathrm{pH} 7.3$ )에 접종하여 $25^{\circ} \mathrm{C}$ 에서 $180 \mathrm{rpm}$ 의 조건 으로 7일간 진탕 배양하였으며 filter paper를 사용하여 배양액 을 여과하였다. 그리고 배양액은 bioassay시험을 위하여 5일 동안 동결건조 후에 30 배 농축하였다. 동결건조를 수행한 내 생진균은 DNeasy Plant mini kit (QIAgen)를 이용하여 genomic DNA를 추출하였다 $[6,7,8,9$,$] . 추출된 genomic DNA는$ universal primer인 ITS1 (5'-TCC GTA GGT GAA CCT GCG G-3') 과 ITS4 (5'-GGA AGT AAA AGT CGT AAC AAG G-3') 를 사용하여 $\mathrm{rDNA}-\mathrm{ITS}$ 영역을 증폭하였다. $\mathrm{PCR}$ 수행 조건은 최종농도 $10 \mathrm{mM}$ Tris- $\mathrm{HCl}(\mathrm{pH} 8.5), 40 \mathrm{mM} \mathrm{KCl}, 1.5 \mathrm{mM}$ $\mathrm{MgCl}_{2}, 200 \mathrm{nM}$ dNTPs 이고, 10 pmol의 primer와 0.1 unit의 Ex-Taq DNA polymerase (Takara)를 사용하였으며, $50 \mathrm{ul}$ 로 반응용량을 맞추어 사용하였다. 반응조건은 predenaturation $\left(95^{\circ} \mathrm{C}, 2 \mathrm{~min}\right)$, denaturation $\left(95^{\circ} \mathrm{C}, 30 \mathrm{sec}\right)$, annealing $\left(54.5^{\circ} \mathrm{C}\right.$, $1 \mathrm{~min})$, extension $\left(72^{\circ} \mathrm{C}, 1 \mathrm{~min}\right)$, total cycles (35 cycles), final extension $\left(72^{\circ} \mathrm{C}, 7 \mathrm{~min}\right)$ 으로 수행하여 $4^{\circ} \mathrm{C}$ 에 보관하였으며, 증폭된 PCR 산물은 $1.5 \%$ Agarose gel에서 전기영동 후, $\mathrm{EtBr}$ (Ethidium bromide)로 10분 염색하여 UV transilluminator에
서 밴드를 확인하였다 $[6,7,8,9,14]$. 그리고 증폭된 단편들은 QIAquick PCR purification kit (Qiagen Inc., Germany)를 사 용하여 정제하였고, ABI PRISM BigDye Terminator Cycle Sequencing Kit (PE Biosystems, USA)를 사용하였으며, 생산 된 DNA 단편들은 ABI 310 DNA sequencer (Perkin elmer, $\mathrm{New}$ Jersey, USA)를 사용하여 분석하였다[14]. 그리고 분석된 내생진균 종들 간에 계통분석은 MEGA 4.1프로그램 Neighbor-Joining (1000 bootstrap replicates)방법을 수행하여 분석하였다[6-9,14].

독도에서 분리한 내생진균의 분자적인 동정을 위하여 rDNA-ITS 영역의 염기서열을 blastn 프로그램을 이용하여 분 석하였으며, 분리된 균류들과 서열 상동성이 가장 높은 균류 들을 분석하였다(Table 2).

식물생장촉진활성을 검정하기 위하여 uniconazol $80 \mathrm{ppm}$ 과 스포탁을 24 시간 처리하였고, 난장이벼 유묘의 이엽기 부 분에 내생진균의 농축배양을 $10 \mu \mathrm{l}$ 처리하여 7 일 동안 유묘의 생장을 측정하였다.

\section{결과 및 고찰}

독도에 서식하고 있는 식물인 참억새에서 4 종, 쇠무릎에서 4 종, 돌피에서 8 종, 갯별꽃에서 3종 그리고 율무쑥에서 2종 으로 모두 21종의 내생진균을 분리하였다. 동도에 자생하는 참억새에서는 Penicillium sp. (75\%)와 Aspergillus sp. (25\%)가 분리 되었고, 쇠무릎에서는 Penicillium sp. (55\%), Aspergillus sp. (30\%) 그리고 Zygorhynchus sp. (15\%)가 분리되었으며, 돌 피에서 Penicillium sp. (50\%), Aspergillus sp. (12\%), Gibberella sp. (13\%), Talaromyces sp. (9\%), Umbelopsis sp. (8\%)가 분리 되었다. 서도에 자생하는 갯별꽃에서 Penicillium sp. (76\%)와 Pestalotiopsis sp. (24\%)가 분리되었고, 율무쑥에서는 Penicillium sp. $(81 \%)$ 와 Mucor sp. (19\%)가 분리되었다(Table 3).

본 연구 결과로 얻어진 내생진균에 대한 계통수는 크게 2가 지로 분류를 할 수 있었다.

첫 번째 그룹은 자낭균류(Ascomycota)로서 참억새에서는 Penicillium sp.와 Aspergillus sp.가 분리동정 되었으며, 쇠무릎 에서는 Penicillium sp.와 Aspergillus sp. 그리고 돌피에서는 Penicillium sp., Aspergillus sp., Gibberella sp. 그리고 Talaromyces sp.를 분리동정 할 수 있었다. 갯별꽃과 율무쑥에 
Table 2. Identification of endophytic fungi in this study

\begin{tabular}{|c|c|c|c|c|c|}
\hline $\begin{array}{l}\text { Sampling } \\
\text { location }\end{array}$ & Host plant \& local & Collection No. & $\begin{array}{l}\text { Closest relative based on partial sequence } \\
\text { homology }\end{array}$ & $\begin{array}{l}\text { Max. } \\
\text { identity }\end{array}$ & $\begin{array}{l}\text { Accession } \\
\text { No. }\end{array}$ \\
\hline \multirow{16}{*}{ Dongdo } & \multirow{4}{*}{ Miscanthus sinensis } & Ms-1-2 & Penicillium minioluteum E3(GU566240) & $96 \%$ & JF327810 \\
\hline & & Ms-1-3 & Penicillium sp. UCD1Syrah(HM849046) & $99 \%$ & JF327811 \\
\hline & & Ms-2-5 & Penicillium glabrum(HM776431) & $93 \%$ & JF327812 \\
\hline & & Ms-2-7 & Aspergillus niger(GU295947) & $100 \%$ & JF327813 \\
\hline & \multirow{4}{*}{ Achyranthes japonica } & Aj-1-2 & Aspergillus tubingensis(HQ315841) & $99 \%$ & JF327814 \\
\hline & & $\mathrm{Aj}-2-5$ & Zygorhynchus moelleri Cr27(FJ590616) & $99 \%$ & JF327815 \\
\hline & & Aj-2-5-2 & Penicillium virgatum IHB F 536(HM461858) & $99 \%$ & JF327816 \\
\hline & & Aj-3-1-1 & Penicillium canescens QLF83(FJ025212) & $100 \%$ & JF327817 \\
\hline & \multirow{8}{*}{$\begin{array}{l}\text { Echinochloa crusgalli } \\
\text { P. Beauv. }\end{array}$} & Ec-2-3 & Penicillium sp. M73(GU446637) & $99 \%$ & JF327818 \\
\hline & & Ec-3-1 & Aspergillus phoenicis(HQ315842) & $100 \%$ & JF327819 \\
\hline & & Ec-3-2 & Gibberella moniliformis(HM776426) & $99 \%$ & JF327820 \\
\hline & & Ec-3-4-3 & Talaromyces flavus(EF123253) & $99 \%$ & JF327821 \\
\hline & & Ec-4-1 & Penicillium citrinum B-57(EU664460) & $99 \%$ & JF327822 \\
\hline & & Ec-5-1 & Penicillium simplicissimum LP33(HQ655814) & $98 \%$ & JF327823 \\
\hline & & Ec-6-2 & Umbelopsis isabellina ODHO4(EU816388) & $97 \%$ & JF327824 \\
\hline & & Ec-6-2-2 & Penicillium urticae JZ-56(HQ637345) & $99 \%$ & JF327825 \\
\hline \multirow{5}{*}{ Seodo } & \multirow{3}{*}{ Honkenya peploides } & Hp-5-2 & Pestalotiopsis clavispora hz-067(FJ517545) & $99 \%$ & JF327826 \\
\hline & & Hp-5-3 & Penicillium variabile FRR 1290(AY373936) & $99 \%$ & JF327827 \\
\hline & & Hp-5-3-1 & Penicillium spinulosum(DQ888735) & $99 \%$ & JF327828 \\
\hline & \multirow{2}{*}{$\begin{array}{l}\text { Artemisia koidzumii } \\
\text { Nakai }\end{array}$} & Ak-1-3 & Penicillium sp. M73(GU446637) & $100 \%$ & JF327829 \\
\hline & & Ak-2-1 & Mucor fragilis Grs14(FJ904925) & $99 \%$ & JF327830 \\
\hline
\end{tabular}

Table 3. Occurrence of endophytic fungi in the root of native plants in Dokdo island

(unit: \%)

\begin{tabular}{lccccc}
\hline & \multicolumn{5}{c}{ Plant samples } \\
\cline { 2 - 6 } Endophytic fungi & Miscanthus sinensis & Achyranthes japonica & Echinochloa crusgalli & Honkenya peploides & Artemisia koidzumii \\
\hline Penicillium sp. & $75 \%$ & $55 \%$ & $51 \%$ & $76 \%$ & - \\
Aspergillus $\mathrm{sp}$. & $25 \%$ & $30 \%$ & $16 \%$ & - & - \\
Zygorhynchus sp. & - & $15 \%$ & - & - & - \\
Gibberella sp. & - & - & $13 \%$ & - & - \\
Talaromycessp. & - & - & $11 \%$ & - & - \\
Umbelopsis sp. & - & - & $9 \%$ & $24 \%$ & - \\
Pestalotiopsis sp. & - & - & - & - & $19 \%$ \\
Mucor sp. & - & - & - & & - \\
\hline
\end{tabular}

서 Penicillium sp.가 공통적으로 분리되었으며 갯별꽃에서 Pestalotiopsis sp.가 분류 되었다. 두 번째 그룹은 Mucoromycotina로서 쇠무릎에서 Zygorhynchus sp.와 돌피에 서 Umbelopsis sp.를 분리동정 할 수 있었고, 율무쑥에서 Mucor $\mathrm{sp}$.가 분리동정 되었다. 동도의 식물로부터는 Penicillium sp.와 Aspergillus sp.가 공통적으로 분리 되었으며, 동도와 서도에서 분리된 식물에서 공통적으로 Penicillium sp.가 가장 많이 분포 하고 있는 것을 알 수 있었다(Fig. 1).

식물생장촉진능을 확인하기 위하여 bioassay를 3반복 수행 하였으며, 돌피에서 분리된 Collection No. Ec-3-1의 내생진균 이 waito-c의 생장을 촉진하는 것을 확인 할 수 있었다. Ec-3-1 의 경우, 식물체길이는 평균 $21.5 \mathrm{~cm}$ 와 지상부길이 $11.5 \mathrm{~cm}$ 로 확인하였다. 통계처리는 실험으로부터 얻은 결과를 SPSS ver$\operatorname{sion} 19.0$ 을 이용하여 각 실험에 대하여 평균표준편차로 표시
하였으며, $p \times 0.05$ 수준에서 T-test로 비교 분석하였다. 그리고 G. fujikuroi와 Ec-3-1균주를 비교하였을 때, 통계적으로 차이가 없었고 거의 비슷한 것을 확인 하였다. Ec-3-1균주의 보다 정확 한 확인을 위하여 배양액의 정량분석이 필요할 것으로 보여진 다(Fig. 2.).

참억새와 돌피에서 분리된 collection No. Ms-1-2와 Ms-2-5 및 Ec-6-2의 ITS영역을 blastn으로 분석하였을 때, maxium identity가 Penicillium sp. (96\%), Penicillium sp. (93\%), Umbelopsis sp. (97\%)인 것을 확인하였다. 그래서 Penicillium sp. (96\%)와 Penicilliumsp. (93\%)는 신균주일 가능성이 있다 고 생각된다.

본 연구는 천연기념물 및 특정도서 제 1 호로 지정된 독도에 서 자생하고 있는 참억새, 쇠무릎, 돌피, 갯별꽃, 율무쑥등 뿌 리내부 진균을 분리하여 동정을 수행하였으며, 아직까지 연구 


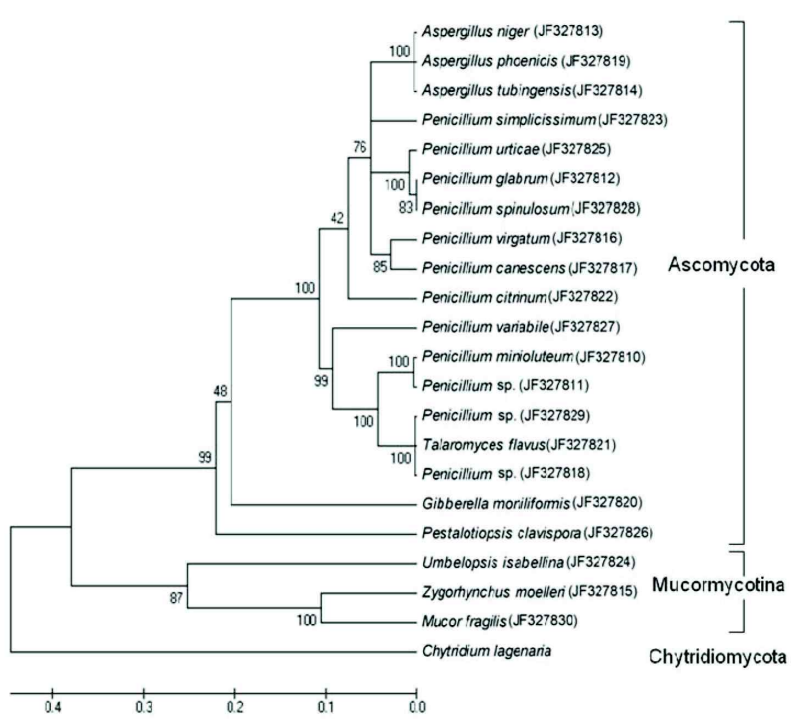

Fig. 1. Phylogenetic analysis of endophytic fungi using rDNA-ITS sequences.

Chytridium lagenaria was used as outgroup for rooting the tree. Neighbour joining tree (1000 bootstrap replications) was constructed using 22 taxa (21 reference sequences and 1 clone). Phylogenetic analysis showed that all isolated fungal strains belong to the phylum Ascomycota or subphylum Mucoromycotina.

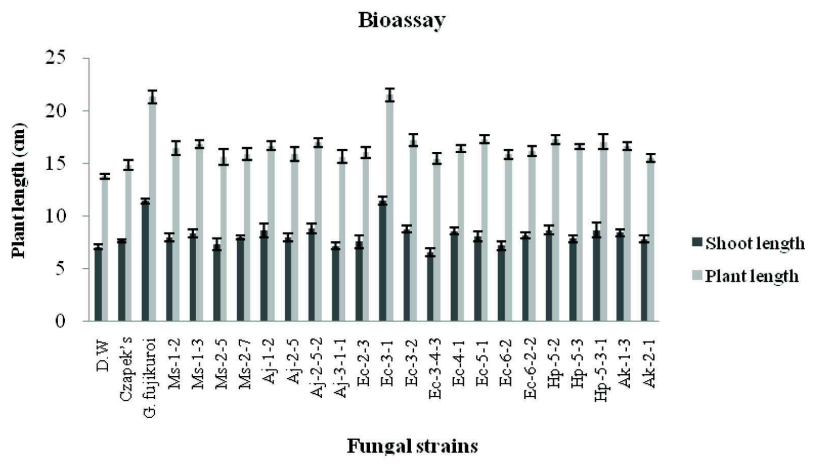

Fig. 2. Effect of fungal culture filtrates on waito-c seedlings after 7 days of incubation.

The fungal strains were cultured for 7 days in Czapek's liquid medium at $25^{\circ} \mathrm{C}, 180 \mathrm{rpm}$. The $10 \mathrm{ul}$ of lyophilized fungal culture filtrate was treated on the waito-c seedlings. Each sample was assayed in triplicate. Whole plant lengths and shoot lengths were measured after 7 days of treatment.

되지 않은 지역에 존재하는 내생진균을 분리동정하여 다양성 을 확인하고자 하였다.

\section{감사의 글}

본 연구는 환경부 “차세대 에코이노베이션기술개발사업”
으로 지원 받은 과제이며, 연구비 지원에 감사를 드립니다.

\section{References}

1. Clay, K. and J. Holah. 1999. Fungal endophyte symbiosis and plant diversity in successional fields. Science 285, 1742-1744.

2. Ham, M. S., Y. M. Park, H. R. Sung, M. Sumayo, C. M. Ryu, S. H. Park, and S. Y. Ghim. 2009. Characterization of rhizobacteria isolated from family Solanaceae plants in Dokdo island. Korean J. Microbiol. Biotechnol. 37, 110-117.

3. Jeon, Y. G. 2005. The regional geomorphology of Dokdo(Volcanic Island). Korean J. Reg. Geol. 11, 19-28.

4. Kim, M. H., Y. J. Oh, C. S. Kim, M. S. Han, J. T. Lee, and Y. E. Na. 2007. The Flora and Vegetation Distribution in Dokdo. Korean J. Environ. Agric. 26, 85-93.

5. Khan, S. A., M. Hamayun, S. O. Rim, I. J. Lee, J. C. Seu, Y. S. Choo, I. N. J, S. D. Kim, I. K. Lee, and J. G. Kim. 2008. Isolation of endophytic fungi capable of plant growth promotion from monocots inhibited in the coastal sand dunes of Korea. Korean J. Life Sci. 18, 1355-1359.

6. Khan, S. A., M. Hamayun, H. Y. Kim, H. J. Yoon, I. J. Lee, and J. G. Kim. 2009. Gibberellin production and plant growth promotion by a newly isolated strain of Gliomastix murorum World J. Microbiol. Biotechnol. 25, 829-833.

7. Khan, S. A., M. Hamayun, H. J. Yoon. H. Y. Kim. S. J. Suh, S. K. Hwang, J. M. Kim, I. J. Lee, Y. S. Choo, U. H. Yoon, W. S. Kong, B. M. Lee, and J. G. Kim. 2008. Plant growth promotion and Penicillium citrinum BMC Microbiol. 8, 231.

8. Khan, S. A., M. Hamayun, H. Y. Kim, H. J. Yoon, J. C. Seo, Y. S. Choo, Y. J. Kil, J. K. Eo, and A. H. Eom. 2009. Molecular identification and diveristy of endophytic fungi isolated from Pinus densiflora in Boeun, Korea. Korean J. Mycol. 37, 130-133.

9. Khan, S. A., M. Hamayun, H. Y. Kim, H. J. Yoon, J. C. Seo, Y. S. Choo, I. J. Lee, S. D. Kim, I. K. Rhee, and J. G. Kim. 2009. A new strain of Arthrinium phaeospermum isolated from Carex kobomugi Ohwi is capable of gibberellin production. Biotechnol. Lett. 31, 283-287.

10. Lee, D. B. and S. U. Joo. 1958. Reinvestigation of the flora of the Dagelet Island. Humani. Sci. Nat. Sci. 3, 223-296.

11. Lee, D. H., S. H. Cho, and J. H. Pak. 2007. The analysis of vascular plant species composition in Dok-do island. Korean J. Plant Taxon 37, 545-563.

12. Park, S. J., I. G. Song, S. J. Park, and D. O. Lim. 2010. The Flora and Vegetation of Dokdo Island in Ulleung-gun, Gyeongsanbuk-do. Korean J. Env. Eco. 24, 264-278.

13. Research Institute for Ullengdo \& Dokdo Islands. 2008. pp.166-221, The plant of Dokdo island. Nature of Dokdo island. Kyungpook National University Press. Daegu. Korea.

14. Seo, S. T., K. H. Kim, M. J. Kim, J. S. Hong, J. H. Park, and S. C. Shin. 2009. Diversity of fungal endophytes from Pinus koraiensis leaves in Korea. Korean J. Mycd. 37, 108-110. 15. Sun, B. Y., M. R. Sul, J. A. Im, C. H. Kim, and T. J. Kim. 
2002. Evolution of endemic vascular plants of Ulleungdo and Dokdo in Korea - floristic and cytotaxonomic characteristics of vascular flora of Dokdo. Korean J. Plant Taxon. 32, 143-158.

16. Shin, H. T., S. J. Park, K. H. Kang, and J. H. Yoo. 2004. The establishment of conservation area and conservation strategy in Ulnung Island. Korean J. Environ. Eco. 18, 221-230.

17. Yoon, J. H., S. Y. Kang, M. H. Lee, and T. K. Oh. 2005. Virgibacillus dokdonensis sp. nov., isolated from a Korean island, Dokdo, located at the edge of the East Sea in Korean. Int. J. Syst. Evol. Microbiol. 51, 1079-1086.

\section{초록 : 독도의 자생식물 뿌리에서 분리한 내생진균의 다양성과 생장촉진활성}

유영현 · 윤혁준 $\cdot$ 이길성 ${ }^{1} \cdot$ 우주리 $\cdot$ 임순옥 $\cdot$ 신재호 ${ }^{2} \cdot$ 이인중 ${ }^{2}$ 추연식 ${ }^{1} \cdot$ 김종국*

(경북대학교 생명공학부, ${ }^{1}$ 경북대학교 생물학과, ${ }^{2}$ 경북대학교 응용생명과학부)

독도에 자생하고 있는 식물의 뿌리로부터 내생진균의 분리를 시도하여, 동도로 부터 참억새, 돌피, 쇠무릎과 서도에서 갯별꽃 및 율무쑥등을 연구재료로 사용하였다. 총 21종의 내생진균을 분리하였고, universal primers ITS-1과 ITS-4를 사용하여 ITS 영역을 PCR로 증폭하여 동정하였다. 염기서열 분석결과, 동도에 자생하는 참억새 에서는 Penicillium 속 균주가

$75 \%$, Aspergillus 균주가 25\%, 분리되었고, 돌피에서는 Penicillium 속 균주가 $55 \%$, Aspergillus 속 균주가 $30 \%$, Zygorhynchus 속 균주가 $15 \%$ 가 분리되었으며, 쇠무릎에서는 Penicillium 속 균주가 $50 \%$, Aspergillus 속 균주가 $12 \%$, Gibberella 속 균주가 13\%, Talaromyces 속 균주가 9\%, Umbelopsis 속 균주가 $8 \%$ 분리되었다. 서도에 자생하는 갯별꽃에서는 Penicillium 속 균주가 76\%, Pestalotiopsis 속 균주가 $24 \%$ 분리되었고, 율무쑥에서는 Penicillium 속 균주가 $81 \%, M u c o r$ 속 균주가 19\% 분리되었다. Bioassay결과, 돌피에서 분리된 Ec-3-1균주가 식물생장촉진활성 을 나타내었다. 그리고 독도의 5종류 식물에서 Penicillium 속의 내생진균이 가장 많이 존재함을 알 수 있었다. 